\title{
İstanbul'un Şehir Tarihine Ayna Tutan Bir Tarihî Polisiye: İstanbul
}

\section{Hatırasi* $^{*}$}

\section{A Historical Detective Which Is Mirroring to The City History of İstanbul: İstanbul Hatırasi}

\author{
Doç. Dr. Sevgül TÜRKMENOĞLU(i) 1
}

\begin{abstract}
$\ddot{O} z$
Ahmet Ümit, polisiye roman türünün Türk edebiyatında en çok okunan temsilcilerinden biridir. Ümit, son yıllarda özellikle tarihi polisiye türündeki romanları ile okuyucunun dikkatini çeker. Romanlarının kurgusunu çok bilinen tarihi bir olay veya kişinin üzerine oturtan Ümit, bu yönüyle de diğer polisiye roman yazarlarından ayrılır. İstanbul Hatırası romanı, Ahmet Ümit'in İstanbul'un tarihi üzerine kurguladığı bir romandır. Romanda İstanbul'un Bizans, Roma, Osmanlı ve Cumhuriyet Dönemi olmak üzere dört ayrı dönemi yer alır. Roman, iki katmanlı bir biçimde ilerler. İlk katman, polisiye kurgudur. Kurgu, yedi farklı cinayet üzerinden bir dedektif-katil romanı şeklinde ilerler. $\mathrm{Bu}$, alışılmış bir polisiye kurgusudur. İkinci katman ise, İstanbul'un dört ayrı dönemdeki mimari ve tarihi yönlerinin öne çıkması üzerine kurgulanmıştır. Asıl karmaşık olan kısım, romanın bu ikinci katmanıdır. Bu ikinci katmanda İstanbul, birçok medeniyete ev sahipliği yapmış kadim bir şehir olarak öne çıkarılır. Zaman içerisinde İstanbul'un mimari ve tarihi dokusuna insan eliyle verilen zarar da eleştirel bir biçimde öne çıkar. Böylece polisiye bir romanın sürükleyiciliğine bir şehir tarihi de eklemlenerek roman kurgulanır.
\end{abstract}

Anahtar Kelimeler: Ahmet Ümit, İstanbul, şehir, polisiye roman, tarih

Makale Türü: Derleme

\begin{abstract}
Ahmet Ümit is one of the most widely read representatives of Turkish detective novelists. Ümit takes attention of the readers especially with his historical detective novels in recent years. Ümit, who sits on fiction of his novels to well-known historical event or person, departs from other fiction writers. The İstanbul Hatırası novel is written by Ahmet Ümit on the history of İstanbul. There are four separate periods of İstanbul in novel: Byzantine, Roman, Ottoman and the Republican Period. The novel progresses in two tiers approach. The first tier is detective fiction. Fiction goes through seven different murders as a detectivekiller novel. This is a usual detective fiction. The second tier is based on the prominence of the architectural and historical aspects of Istanbul in four different periods. The main complex part is the second tier of novel. In this second tier, İstanbul is highlighted as a city that has been hosted by many civilizations. Over time, human-caused damage to the architectural and historical texture of İstanbul also comes to the forefront. Thus, the novel is fictionalised by attaching a city history to the drift of a detective novel.
\end{abstract}

Keywords: Ahmet Ümit, İstanbul, city, detective novel, history

Paper Type: Review

\footnotetext{
*Bu çalışmanın ilk hali 03-05 Mayıs 2018 tarihleri arasında Alanya Alaattin Keykubat Üniversitesi’nde düzenlenen 4. Uluslararası Asoscongress Filoloji Sempozyumu'nda sözlü bildiri olarak sunulmuştur.

${ }^{1}$ Van Yüzüncü Y1l Üniversitesi, Eğitim Fakültesi, se_cabaz@hotmail.com.
}

Atıf için (to cite): Türkmenoğlu, S. (2019). İstanbul'un Şehir Tarihine Ayna Tutan Bir Tarihî Polisiye: İstanbul Hatırası. Afyon Kocatepe Üniversitesi Sosyal Bilimler Dergisi, 21(4), 1072-1084. 


\section{Giriş}

İstanbul Hatırası*, Ahmet Ümit'in 2010 yılında yayımlanan romanıdır. Roman, yalnızca bir polisiye özelliği göstermez. İstanbul'un Bizans, Roma ve Osmanlı dönemlerine ait pek çok tarihi bilgiyi içermesi yönüyle de dikkat çeker. Yazar, romanın sonuna üç sayfalık bir kaynakça eklemiştir. Kaynakçada Evliya Çelebi, Reşad Ekrem Koçu, Halil İnalcık, Semavi Eyice, İlber Ortayl1, Jak Deleon, Stefanos Yerasimos gibi İstanbul'a ve İstanbul tarihine dair önemli çalışmaları bulunan isimlerin eserlerine yer verilmiştir. Bu durum romanı "dikkatini o konularda yoğunlaştıran okur için ilginç" (Aytaç 2012:438) kılar. Ümit, bu yöntemle, büyük okur kitlesine ulaşma çabasına da katkı sağlar. (Aytaç 2012:438) Yazara göre: "Polisiye yazarının, hem bir mimar, hem bir dil uzmanı, hem bir siyasi analizci, hem bir psikoloji uzmani, hem bir sinemacl (kurgucu), hem bir araştırmacı, hem de bir felsefeci" (Gülgûn 2002) olmas1 gerekir.

Ümit, İstanbul Hatırası'nı bir tarih bilinciyle yazmaya başladığını söyler: “Anadolu tarihinin farkına varınca, İstanbul'da yaşayan bir yazar olarak bende bir şehir romanı yazma isteği ortaya çıktı" (Sayın 2010:25). Romanın kurgusu içine İstanbul'un tarihine dair pek çok ayrıntı serpiştirilmiştir. Romanın kurgusu tarihi yapılarla ilişkilendirilerek oluşturulmuştur. Romanda yedi gün içinde işlenen yedi cinayet ve kurbanların her birinin bırakıldığ 1 yedi tarihi mekân vardır. Yedi sayısı romanın kurgu bütünlüğü içinde önem teşkil eder. Yazarın yedi sayısını, İstanbul'un yedi tepe üzerine kurulduğu efsanesine göndermede bulunmak için tercih ettiği düşünülebilir. Ahmet Ümit kendisiyle yapılan bir röportajda romanda yedi sayısının rolünü şöyle anlatır:

"Bu romanın baş kahramanı, İstanbul. Bir yazar, başkarakterinin bütün derinliklerini anlatmayı tercih eder. Dedim ki, üç bin yıla yakın bu tarihi nasıl anlatırım? Roman yedi günde geçiyor, yedi cinayet var. Yedi simge seçtim: Kral Byzas, Konstantinopolis'in doğuşu, kara surlart, Ayasofya, Fatih Sultan Mehmet dönemi, Kanuni, Mimar Sinan ve günümüz Türkiye'si", (Özkartal 2010)

Yazar, romanın adını niçin İstanbul Hatırası olarak seçtiğini de şöyle dile getirir:

"Bir oyun var o adda. Eskiden fotoğrafların fonu olan İstanbul Hatırasi yazısı gibi algılanıyor, ama öyle değil. Burada hatıradan kastım "yadigâr". Kahramanlarımın İstanbul'a "Sana kendimizi adıyoruz" demesi. Bunu okur ancak, kitabın sonunu okuduğunda anlayacak. "(Özkartal 2010)

Bir hayli hacimli ve çerçeve anlatılarla zenginleştirilen romanda tarih, mimari ve bir şehrin tarihinin hoyratça yok edilişi cinaî kurguyla bir arada ilerler. Yazarın polisiye ile tarihi bir arada yürüttüğü roman, bu sebeple karmaşıktır. Tarihi bilgiler, romanın içine serpiştirilen çerçeve hikâyeler bu karmaşıklığın başlıca sebebidir. Bununla birlikte, polisiye romanın en önemli unsuru olan gerilim roman boyunca sekteye uğramaz.

\section{Olay Örgüsü:}

"İstanbul kimsenin umurunda değil"

İstanbul Hatırası, kısmen postmodern bir roman olarak değerlendirilebilir. Tarihi bir roman olma özelliği de taşıdığı için, postmodern anlatıların sıkça başvurduğu yeni tarihselcilik anlayışından istifade etmiş olması dikkat çeker. Opperman'ın yeni tarihselcilik anlayışı için söylediği:

"Tarihin metinselliği/ kurgulanabilir bir disiplin oluşu, onun sadece dil (lisan) içerisinde gerçekleşebileceği kabulü, kaydedilmiş gerçeklerin bile tarihçi tarafindan yeniden yorumlanarak ortaya çıkartması süreci, "tarih" kavramının geleneksel anlamını, temelden sarsmış ve tarihe yeni bir anlam kazandırmıştır" (Yalçın Çelik 2005:25) tespiti, İstanbul Hatırası romanına

\footnotetext{
* İstanbul Hatırası, 13. Bas., Everest Yayınları, İstanbul, 2010 (Çalışmamızda parantez içinde verilen sayfa numaralı eserin bu baskısına aittir.)
} 
yansımıştır. Yazar, kurgunun içine tarihi eklemleyerek kurgu ile bir arada ilerletir. Postmodernist yazarların polisiye unsurlara, melodram romantizmine, ya da tarihsel romanın nostaljisine yöneldikleri (Ecevit 2006:179) bilinir. İstanbul Hatırası'nda bu durumun izlerini görmek mümkündür.

Romanda çok zincirli bir olay örgüsü vardır. İlk zincir, işlenen cinayetler üzerinden verilir. İkinci zincir, İstanbul'un ilk kurulduğu dönemden itibaren başlayan hikâyesidir. Bu iki olay zinciri birbiri ile eş zamanlı ilerler. İlk olay zincirinde çerçeve hikâye olarak roman kahramanlarının irili ufaklı hikâyelerine de yer verilir.

Roman, yedi bölümden oluşur. Eserde, bir yapbozun parçaları gibi yedi cinayet, yedi mekân ve yedi günlük zaman dilimi birbirini tamamlar. Bu, tıpkı bir oyun gibidir. Nitekim yazar, kendisiyle yapılan bir röportajda da polisiye kurgularında bir oyun barındırdığını söyler:

"Polisiye yazarı bir oyun kurar ve siz o oyunun içine girersiniz. Oyunu kuran adamla oynarsiniz" (Oktay 2003).

Bölümler oluşturulurken Bizans’tan günümüze kadar gelen bir İstanbul serüveni esas alınır. Bu bölümler şu başlıkları taşır:

1. Byzantion: Kral Byzas'ın Efsanevi kenti

2. Constantinopolis: Constantinus'un Başkenti

3. Konstantinopolis'i Koruyan Taştan Zırh: II. Teodosius'un Surları

4. Küllerinden Doğan Kent: Iustinianus'un Konstantinopolis'i

5. Konstantiniyye: Fatih Sultan Mehmed'in Gül Bahçesi

6. Kanuni Sultan Süleyman'in Payitaht1, Mimar Sinan'ın Şehri

7. Bizim İstanbulumuz: Çalınan Umutların Şehri

Her bölümde İstanbul'u yöneten kudretli bir hükümdara işaret eden Ümit, 7. Bölümün adını, Bizim İstanbul'umuz: Çalınan Umutların Şehri olarak belirler. Daha önceki altı bölümün isimleri yukarıda da verildiği gibi o dönem hükümdarının gücünü, kudretini ve şehrin heybetini yansitırken, son bölümde İstanbul'un çalınan umutların şehri olarak tabir edilmesi romanın genel havasına ve romanda işlenen cinayetlerin gerekçesine de uygundur. Romanda yedi günde işlenen yedi cinayette de katillerin gerekçesi, kurbanların İstanbul'a, şehrin tarihi dokusuna ve mimarisine maddi çıkarları için zarar vermeleridir. İşlenen cinayetler, bir bakıma şehre verilen zararın diyetini almak gibi algılanmaktadır. Yazar, bir röportajında bu duruma şöyle açıklık getirir:

"Bunlar seri katil değil. Evet yedi günde yedi cinayet var; ama seri katil profili diyemeyiz. Buradaki cinayetler bir tür anlam cinayetleri. Seri katiller psikolojik tatmin için öldürürler, vicdanları yoktur. Romandaki katillerin ise vicdanları var, bu yüzden öldürüyorlar zaten." (Özkartal 2010)

Romanda öldürülen yedi kişi, meslekleri itibariyle sanat tarihçisi, mimar, arkeolog gibi toplum içinde aydın olarak görülen kimselerdir ve hepsinin ortak noktası yukarıda da değinildiği gibi İstanbul'un tarihi dokusuna, zengin olmak uğruna, zarar vermeleridir.

Romanda ardı ardına işlenen yedi cinayet de birbiriyle bağlantılı olduğu için ve bir cinayetin hemen arkasından bir başka cinayet işlendiği için aksiyon hep yüksektir. Her kurban, tarihi bir mekânda elleri bağlanıp avuçlarına bir tarihi sikke konmuş halde bulunur. Her birinin yatırılış pozisyonu gizemlidir. Bu pozisyonlar ve kurbanların avucundaki sikkeler bir sonraki kurbanın bırakılacağı tarihî mekânı işaret eder. Başkomiser Nevzat, cinayetlerin izini sürerken bu gizemli şifreyi de çözmeye çalışır. Her kurbanın avucuna bırakılan sikke, cesedin bırakıldığı tarihi yapının ait olduğu dönemin hükümdarı adına bastırılmıştır. Romanda maktullerin adları, meslekleri, cesetlerinin bırakıldığı yer ve avuçlarındaki sikkelerin ait olduğu dönem şu şekildedir:

1. Necdet Denizel: Sanat tarihçisi ve arkeolog olarak geçer. Sarayburnu'nda Poseidon Tapınağı civarında Atatürk heykelinin yanına bırakılan cesedin elleri bağlıdır ve avucuna "Roma 
döneminde basilan madeni paralardan” (s.38) olan Kral Byzos sikkesi konmuştur. Sarayburnu, Kral Byzantion döneminde şehrin ilk kurulduğu yerdir. (s.62)

2. Mukadder Kınacı: Şehir planlamacısı olan Mukadder Kınacı, "belediyeye bağlı bir kurumda görev yap[ar]” (s.123). Cesedi Çemberlitaş’ta, Çemberlitaş sütununun yakınında bulunur. Ceset, "ayakları iki yana ayrılmış, kolları geriye doğru dümdüz uzatılmış, ellerinin ayaları yüz yüze gelecek şekilde naylon bir iple birbirine bağlanmıştı[r]”(s.99). Avucunda da Çemberlitaş sütununun da onuruna yaptırıldığı imparator 1 . Konstantin adına bastırılmış bir sikke vardir.

3. Şadan Duruca: Şadan Duruca gazetecidir. Cesedi, Yedikule'de Altınkapı'nın önünde bulunur. İlk iki maktul gibi bir pozisyon verilmiştir. Avucunda Roma imparatoru II. Teodosius dönemine ait bir sikke vardır. Altınkapı, Roma döneminde zafer kazanan imparatorların kente girerken kullandıkları bir kapıdır. (s.211)

4. Teoman Akkan: Mimar olan Teoman Akkan'ın cesedi, Ayasofya'da, "müzenin yan sokağında" (s.315) bulunur. Teoman Akkan'ın cesedi daha önceki üç kurbandan farklı bir biçimde kolları iki yana açılmış şekilde durmaktadır ve avucunda imparator Jüstinyen dönemine ait bir sikke bulunur.

5. Fazlı Gümüş: Fazlı Gümüş, eski belediye başkan yardımcısıdır. Cesedi Fatih Camii bahçesinde bulunur. Başı gövdesinden ayrılıp, kargo ile Topkapı Sarayı Müzesi'ne, müze müdiresi Leyla Barkın'a gönderilir. (s.396). Kurbanın avucunda Fatih Sultan Mehmed adına bastırılmış sikke vardır.

6. Hakan Yamalı: Avukat olan Hakan Yamalı'nın cesedi Süleymaniye'de bulunan Mimar Sinan'ın türbesi yanında bir minübüsün içinde bulunur (s.508). Avucunda Kanuni Sultan Süleyman adına bastırılmış bir sikke vardır.

7. Adem Yezdan: Turizm işiyle uğraşan Adem Yezdan, çok zengin bir işadamıdır. İstanbul'a zarar veren yukarıdaki altı kurbanı yönlendiren ve zengin olmak uğruna şehre en büyük tahribatı veren kişidir. Cesedi Sarayburnu'nda Atatürk heykelinin önünde bulunur. (s.546) Burası aynı zamanda ilk kurbanın da cesedinin bırakıldığ 1 yerdir. Katiller, başladıkları yere son cinayetle geri dönmüşlerdir. Âdem Yezdan'in avucunda sikke yoktur.

Yukarıdaki kurbanların yedisi de zekice kurgulanmış ve birbirinin devamı sayılabilecek cinayetlerle öldürülmüşlerdir. Yazarın ifadesiyle "katil, işlediği cinayetlerle bu şehri kuran, başkent yapan, imar eden hükümdarlara gönderme yap[ar]” (s.125).

Romanda olaylar hep sicak ve sürükleyicidir. Cinayetler, üzerinden 24 saat bile geçmeden arka arkaya işlenir. İkinci olay zinciri olan İstanbul'un tarihine, kurbanların avuçlarındaki sikkelerle giriş yapılır. Sikkelerin üzerinde resmi bulunan hükümdarlar döneminde İstanbul'a kazandırılan mimari yapılar, şehrin tarihine ait bilgiler de kurgu içinde yerini alır. İlk zincir ile ikinci zincir, yani cinayetlerle şehrin tarihi iç içe geçmiş bir şekilde ilerler.

Olayların çözülmesi işine, ilk kurban Necdet Denizel'in kartvizitiyle başlanır. Bu kartvizitten Necdet Denizel'in Samatya'daki evini bulan Başkomiser Nevzat ve arkadaşları eve girdiklerinde Jako cinsi bir papağanla karşılaşırlar. Papağan onları "Merhaba ... Ben Kral Byzas ... Sarayıma hoş geldiniz." (s.21) diye karşılar. Bu, romanın henüz çok başındaki bir bölümdür ve papağan eve biraz gizem havası katsa da henüz anahtar bir rol üstlendiği okuyucu tarafından bilinmemektedir. Baş komiser Nevzat ve arkadaşları evde yaptıkları tahkikat sonucu Necdet'in eski karısı ve aynı zamanda Topkapı Sarayı müdiresi Leyla Barkın'a ulaşırlar. Leyla Barkın, o an için birinci derecede şüpheli durumundadır. Daha sonra Leyla Barkın'ın sevgilisi Namık Karaman romana dâhil olur. Namık da şüpheli konumundadır. Cerrah olan Namık Karaman, Çapa Tıp Fakültesi'nde çalışmaktadır. Yazarın, Namık Karaman'a cerrahlık mesleğini uygun görmesi, ilk kurbanın boynundaki kesikle bu meslek arasında bağlantı kurarak okuyucunun şüphesini Namık üzerine çekmesiyle yorumlanabilir. 
Namık Karaman'ın İSD (İstanbul'u Savunma Derneği) adlı bir derneğe üye olması ve bu derneğin İstanbul'un yöneticiler eliyle ya da zengin olmak uğruna bazı iş adamları tarafından tahrip edilişine karşı çıkması da Namık üzerindeki şüpheleri arttırır.

Romanın başlarında Leyla Barkın ve Namık Karaman üzerine şüpheler yoğunlaşırken bir taraftan da çerçeve hikâye olarak Başkomiser Nevzat'ın hayat hikâyesine yer verilir. Karısı ve kızını bir kazada kaybeden Başkomiser Nevzat, Rum sevgilisi Evgenia ile acısını unutmaya çalışır. Nevzat'ın, Evgenia dışında Demir ve Yekta adında iki çocukluk arkadaşı da vardır. Demir, veteriner; Yekta ise mimar ve şairdir. Nevzat'ın hikâyesine ek olarak Demir ve Yekta'nın hayatları da çerçeve hikâye olarak kurguda yerini alır.

Nevzat, Demir ve Yekta aynı mahallede büyürler. Üçü de yine çocukluk arkadaşları Handan'a âşıktırlar; fakat Handan Yekta ile evlenir. Bir erkek çocukları olur. Handan ve oğlu bir gün yolda yürürken bir inşaatın duvarı üzerlerine çöker ve her ikisinin de ölümüne sebep olur. $\mathrm{Bu}$ bilgi romanın başında, romandaki polisiye olaylarla ilgisi olmayan bir ayrıntı gibi görünse de ilerleyen bölümlerde kilit bir bilgi olduğu fark edilecektir.

Romanın başında şüphelenilen Namık Karaman'ın yapılan tahkikat sonucu sabıkalı olduğu ortaya çıkar. Bu durum, şüpheleri Namık üzerinde daha da yoğunlaştırır:

"Bu Namı teröristmiş. Yani gençlik yillarında. 12 Eylül döneminde polisler evini basmışlar. Silahla karşılık vermiş. İki polisi vurmuş, kendisi kaçarken yaralanmış. Onun da yarası ciddiymiş. İki ay kadar hastanede yatmış, müebbet hapis cezasına çarptırılmış.” (s.109). Namık Karaman'ın geçmişine ait bu ayrıntı onun üzerindeki şüphelerin bir müddet devam etmesine sebep olur. Bununla birlikte Başkomiser Nevzat, Namık ve derneğinin İstanbul'un tarihi dokusunu korumak adına yaptıkları eylemleri ve çabalarını içten içe destekler. Bu sebeple Namık'1 hemen gözaltına almaz:

"Bilinçaltımın verdiği bir işaretle bugüne kadar kimseyi içeri almamıştır, bundan sonra da almayacaktım. Hele Namık gibi İstanbul için bir şeyler yapmaya çalışan birini asla. Yine de onu yeterince tanımadı̆̆ımı biliyordum. Ve yine biliyordum ki, katiller her zaman kötü insanların arasından çıkmazdl.” (s.119).

İlk maktul Necdet Denizel'in çok zengin bir iş adamı olan Âdem Yezdan ile bağ olduğunun öğrenilmesiyle cinayet daha karmaşık bir hal alır. Leyla Barkın, Necdet Denizel ile Âdem Yezdan arasındaki münasebeti Başkomiser Nevzat'a anlatır:

"Adem Yezdan tarihi yarımadada, özellikle de Sultanahmet civarında iş yapmak istiyor. Butik oteller zincirinden tutun da büyük bir iş merkezi yapmaya kadar birçok projesi var. Ancak bu bölgede inşaat yapmak çok zor. Bu yüzden bölgeyi ve mevzuat iyi bilen birine ihtiyacı vardl. İçeriden birine, işte bu pis işin talibi de Necdet oldu." (s.131)

Mukadder Kınacı cinayetinden sonra olayın Hizbullah ve El-Kaide gibi terör örgütlerine mensup kişilerce işlenmiş olabileceğine dair birtakım şüpheler uyanır. Romana, şüpheli olarak Mukadder Kınacı'nın damadı Ömer ve nişanlısı Efsun da dâhil olur. Burada bir çerçeve hikâye daha dikkat çeker. Ömer, tıp öğrencisidir. Babası Kuddusi Zenbar Hoca adlı bir tarikat şeyhine bağlıdır. $\mathrm{O}$ da bu geleneğin içinde büyür. Öğrenciliği sırasında bir arkadaşının etkisinde kalarak cihad gayesiyle Afganistan'a gider. Taliban güçleriyle çatışan bir Amerikalı binbaşının boğazını kesmesi istenir. Ömer bunu dener, fakat yapamaz. Bunun üzerine oradan tekrar Türkiye'ye gönderilir. (s.248-249). Efsun, babasına öfkelidir. Babası, felçli annesini terk ederek kendinden yaşça çok küçük bir kadınla evlenmiştir.

Efsun kısa sürede aklanır. Ömer' in Afganistan seyahatinin yanında, tatillerde kasap olan babasına yardım etmesi (s.226), tıp öğrencisi olması ve maktullerin boğazlarının kesilerek öldürülmesi Ömer üzerindeki şüphe ve soru işaretlerini yoğunlaştırır.

Romana bir taraftan bu çerçeve hikâyeler eşlik ederken, zaman zaman gerilim yükselir. Ömer ve ailesi ile ilgili entegre et tesisi sahibi oldukları bilgisinden hemen sonra Başkomiser Nevzat ve yardımcısı Ali'nin Eğrikapı civarında bir gece yarısı takibe aldıkları et taşıma aracı ve aracın içindeki üzerinde kan lekeleri bulunan poşet (s.231) bir müddet gerilimi tırmandırır; fakat daha sonra "et taşıma aracı temiz çıktı" (s.325) bilgisinin Başkomiser Nevzat'a verilmesiyle bu şüphe de ortadan kalkar. 
Romanda adı sık sık geçen ve gizemini koruyan iş adamı Âdem Yezdan romanın sonlarına doğru kurguya dâhil olur. O zamana kadar, Leyla Barkın ile Başkomiser Nevzat'ın konuşmalarında adı geçen Âdem Yezdan'ın Dersaadet Turizm adında bir şirketi vardır ve şirketin "Cankurtaran sirtlarındaki taştan yapılma üç katlı binası" (s.345) gösterişli bir şekilde "sahte bir Roma sarayl gibi”" (s.345) durmaktadır.

Başkomiser Nevzat ve yardımcısı Ali'nin Âdem Yezdan'ı sorgulamak amacıyla ziyaret ettiklerinde ilk dikkatlerini çeken, Âdem Yezdan'1n ofisinde "Merhaba, ben Teodora...(...) Sarayıma hoş geldiniz."(s.359) diye onları karşılayan Jako cinsi papağandır. Bu papağan, okuyucuya romanın başında ilk kurban olan Necdet Denizel'in evinde karşılaşılan Kral Byzas isimli papağanı hatırlatır. Bu papağanı Nedet Denizel'e gönderen Âdem Yezdan'dır. (s.360). Âdem Yezdan'ın Jako papağanlarına olan ilgisi de yine, cinayetlerin seyri ile ilgili bir ipucudur.

Başkomiser Nevzat, Âdem Yezdan ile görüştükten kısa bir süre sonra Leyla Barkın ile Topkapı Sarayı'nda buluşur. O sırada Leyla Barkın'a bir kargo paketi gelir. Paketi Nevzat'ın yanında açan Leyla Barkın, eski belediye başkan yardımcısı Fazlı Gümüş'e ait kesik baş ile karşılaşır. Başkomiser Nevzat ve yardımcıları Zeynep ile Ali cinayet üzerine kafa yorarken Leyla Barkın ile Namık Karaman'ı tekrar takibe alırlar. Bir gece vakti Namık, Leyla'nın evine gider. Polisler de evi gözetlerler. Leyla Barkın ve Namık Karaman ile birlikte evden iki kişinin çıktı̆̆ını görürler. Bir minübüsün içine koydukları "bezlerle sarıll yük" (s.428) Nevzat'ın dikkatini çeker. Bir süre devam eden takip sonrası eski bir polis olan ve Âdem Yezdan'ın korumalığını yapan Ercan ile İSD üyeleri arasında arbede yaşanır. Namık Karaman, polislerden birine yumruk atar ve burnunu kırar. Minibüste yapılan aramada İSD mensubu olduğu sonradan anlaşılan gençlerin Namık Karaman öncülüğünde bir protesto için afiş taşıdıkları anlaşılır (s.428-429). Bu durum anlaşılıncaya kadar geçen süreçte roman gerilimli bir atmosferde devam eder.

Romanda gerek her cinayet sonrası katillerin kurbanların avuçlarına koydukları eski sikkeler, gerekse cesetlerin bırakıldığ 1 tarihi mekânlar üzerinden İstanbul'un Bizans, Roma ve Osmanlı dönemine dair bilgiler, gerilimli bir kurguya eşlik ederek senkronize bir şekilde verilir. Okuyucu romandaki bu süreci takip ederken Başkomiser Nevzat ve arkadaşlarıyla birlikte bir yapbozun parçalarını birleştirerek bir anlam çıkarma gayreti içine girer. Tarihi bilgiler, bir yığın şeklinde değil, yeri geldikçe ve kurgu ile bağlantılı bir şekilde işlenir. Şehir tarihine ait bilgiler ve gizemli cinayetler kurguyu daha da karmaşıklaştırır.

Romanın son 40 sayfasından itibaren romandaki çözülüşe dair birtakım ipuçları dikkat çeker. Beşinci cinayetten sonra hiçbir ipucuna ulaşamayan ve bu yüzden çaresizlik içinde olan Başkomiser Nevzat, tekrar Âdem Yezdan ile konuşma gereği duyar ve görüşmeye gider. Âdem Yezdan, Başkomiser Nevzat ile olan görüşmesinden sonra başka bir randevuya gitmeyi planlamaktadır ve bunu sohbet sirasinda dile getirir:

"Bizim veteriner bir çift yeni papağan bulmuş bana... Gidip onları alacağım."(s.461) Başkomiser Nevzat, Âdem Yezdan ile konuştuktan sonra Süleymaniye Camii civarına gider. Gece vakti ekip arkadaşlarıyla burada şüpheli bir durum olup olmadığını araştıır. Mimar Sinan türbesinin yakınındaki bir minibüsten çok kötü kokular geldiğini fark edince minibüsün kapısını açarlar ve altıncı ceset ile karşılaşırlar. Bu ceset Âdem Yezdan'ın avukatı Hakan Yamalı'ya aittir. (s.508)

$\mathrm{Bu}$ cinayetten sonra, hepsi birbiriyle ve en önemlisi Âdem Yezdan ile ilişkili olan bu kişilerin arka arkaya öldürülmesi Komiser Nevzat'1 endişelendirir. Âdem Yezdan ile tekrar konuşmak için Dersaadet Turizm'e gider. Âdem Yezdan ofisinde yoktur. Odasını açtırıp görüşebileceği kişilerin kartvizitlerini karıştırır. Orada hiç beklemediği bir kişinin kartviziti vardır: Veteriner arkadaşı Demir'in kartviziti. Âdem Yezdan'ın gündüz kendisine bir veterinerle randevusu olduğunu söylediği aklına gelir. Bir anda bütün eksik parçalar zihninde yerine oturur. Yekta'nın karısı ve oğlu, Âdem Yezdan'ın sahibi olduğu inşaatın duvarının çökmesi sonucu ölmüştür. (s.527)

Nevzat, Âdem Yezdan'ın cesedinin bırakılacağı yeri de gizlice gittiği Yekta'nın evinde, sikkelerle ilgili bir kitaptan bulur. Her kurbanın avucuna bırakılan sikke işaretlenmiştir. Her kurban, avucuna konan sikkenin adına bastırıldığ 1 hükümdarın yaptırdığı bir tarihi eserin yanına bırakıldığı için yedinci sikkeye bakan Nevzat, Âdem Yezdan'ın bırakılacağı yeri kolayca tahmin 
eder. Yedinci para, 1935 yılında basılan bir kuruştur ve Cumhuriyet dönemini işaret etmektedir. Leyla Barkın ile bu konuda görüşen Nevzat, cinayetlerin başladığı yerde son bulacağı sonucuna ulaşır ve ilk kurbanın bırakıldığı Sarayburnu'ndaki Atatürk Anıtı'na yönelir. Tahmini doğru çıkmıştır. Âdem Yezdan'ın cesedi buradadır ve Demir de silahıyla cesedin başındadır. Etrafını da Ali ve Zeynep eşliğindeki bir grup polis sarmıştır. Demir, her şeyi itiraf eder. Cinayetleri Yekta ile birlikte planlamışlardır. Hem şehre zarar veren hem de Handan ile oğlunun ölümüne sebep olan bu yedi kişiyi iki arkadaş planlı bir şekilde öldürmüşlerdir. Romanın sonunda Demir, polis kurşunuyla öldürülürken Yekta karısı ve oğlunun mezarı başında tabancası ile intihar eder.

\section{Kişiler}

“Anlamıyor musunuz, biz kurbanız!"

Roman, oldukça hacimli olmakla birlikte şahıs kadrosu çok kalabalık değildir. Yazarın, Şeytan Ayrıntıda Gizlidir, Kavim, Sultanı Öldürmek, Beyoğlu'nun En Güzel Abisi eserlerinde de yer verdiği Başkomiser Nevzat, romanın dedektifi konumundadır. Ümit'in romanlarında klasik dönem polisiye romanlarının aksine özel dedektifler yoktur. Bu romanlardaki dedektifler ya meraklı bir gazeteci, arkeolog veya amatör bir fotoğrafçı ya da bir istihbaratçı, bir başkomiser olarak (Gezer 2006:63) dikkat çekerler. Başkomiser Nevzat da bu tarz bir kahramandır. Balat'ta yalnız başına yaşar. Annesi tarih öğretmeni olduğu için tarihe merakı vardır. Nevzat'ın annesinin tarihçi olması bilinçli bir seçimdir. Yazar roman boyunca İstanbul tarihine dair birçok bilgiye yer verdiği için bu bilgilerin zeminini bu şekilde hazırlamak ister. Karısı ile kızını bir trafik kazasında kaybeden Başkomiser Nevzat, Rum sevgilisi Evgenia ile yalnızlığını ve acısını unutmaya çalışır. Tatavla'da meyhane işleten Evgenia, anlayışlı ve Nevzat'ın acısına saygılı bir kadındır. Nevzat, onun yanında kendini huzurlu hisseder. Bu sebeple de Evgenia onun yalnızlığını hafifleten hayatındaki çok az insandan biridir. Nevzat, anlayışlı bir kadın olan Evgenia'yı zaman zaman bir sevgiliden çok bir dost olarak görür:

“(...) Illişkiniz olan bir kadına eski karınızdan bahsederseniz bir tür yabancılaşma yaşanır, bizde öyle olmadı ne Evgenia sözlerimi yadırgadı ne de ben ondan uzaklaştım. Belki de bizimki bir kadınla erkek arasındaki sevginin ötesinde bir durumdu, belki de bu gerçek bir dostluktu." (s.79)

Evgenia, Başkomiser Nevzat için monoton ve stresli yaşantısının zorluğu içinde bir nefes alma vesilesidir. Nevzat ona olan hayranlığını şu cümlelerle dile getirir:

"Ĕ̆ger Evgenia ile birlikteyseniz ne aşk küllenir, ne tutku söner. Onun heyecanı, hesapsız bağlllığl, hayata umutla sarılışl ilişkiyi her zaman canl, sevginizi her zaman ayakta tutar. Hatta sizi yavaşlatan yılların yorgunluğuna, çiçekten prangalar gibi ayağınıza sarılan geçmişin acı anılarına rağmen, Evgenia'nın estirdiği o tatl rüzgâr yüreğinizdeki acıyl, kederi dağıtır, size hayata yeniden başlama gücü verir." (s.79)

Evgenia'nın romanın kurgusu içindeki rolü daha ziyade romanın gerilimli atmosferini kırıp biraz da olsa hem Başkomiser Nevzat'a hem de okuyucuya bir soluklanma anı bırakmasıdır. Romanda Evgenia ve Nevzat iki kez Evgenia'nın evinde buluşurlar. Birinde ikisi baş başadırlar. İkincisinde ise onlara Nevzat'ın çocukluk arkadaşları Demir ve Yekta eşlik eder. Sofra başında eski günler yâd edilir. Sakin bir ortamda akşam yemeği yenir. (s.19, 476-477-478)

Romanda, Başkomiser Nevzat ile birlikte cinayetlerin izini süren Ali ile Zeynep adında iki polis vardır. Ali, "kaba saba" (s.12) bir gençtir. Yetiştirme yurdunda büyümüştür. Yurt görevlilerden gördüğü şiddet ve kötü muameleden dolayı (s.140-141) sert mizaçlıdır. Özünde iyi bir insan olmasına rağmen, özellikle zanlılara karşı çok sert ve fevrî davranır. Ali, Zeynep'e âşıtır. Zeynep, romanda dış görünüşü ve ruh haliyle çok derinlemesine ele alınmaz. Cinayetlerin aydınlatılmasında Nevzat ve Ali'ye büyük yardımları dokunur.

Romanda önemli rol üstlenen isimlerden biri, Topkapı Müzesi müdiresi Leyla Barkın'dır. Leyla Barkın, orta yaşta, güzel bir kadındır. (s.28). İlk kurban Necdet Denizel'in eski karısıdır. 
İyi bir tarih bilgisine sahip olan Leyla Barkın, İstanbul'un tarihi yapıları hakkında Başkomiser Nevzat'a roman boyunca bilgi verir. Başkomiser Nevzat, her cinayet sonrası katillerin kurbanlarını bıraktıkları tarihi mekânların gizemini çözmek için Leyla Barkın’a başvurur. Leyla Barkın, romanın başlarında cinayetlerle ilgisi olabileceği düşünülerek şüpheli konumundadır. Özellikle ilk kurban olan Necdet Denizel ile bir zamanlar evli olması romanın başında şüpheleri onun üzerinde yoğunlaştırır. İlerleyen bölümlerde bu şüpheler azalır. Leyla Barkın'ın romandaki en önemli fonksiyonu yukarıda da belirtildiği gibi cinayetlerin işlenişinde kullanılan mekân ve sikkelerin sırrını çözmekte Başkomiser Nevzat'a yardımcı olmaktır.

Romanın başlarında şüpheli sıfatıyla görülen kişilerden biri de Namık Karaman'dır. Cerrah olan Namık Karaman, "Çapa Tıp Fakültesi'nde çalışır." (s.41). Namık Karaman, bir İstanbul hayranıdır. İstanbul'u Savunma Derneği (ISDD) adlı bir derneğe üyedir. Derneğin çalışmalarını, "kentin tarihine sahip çıkma girişimi" (s.56) olarak tanımlar ve bu derneğin çatısı altında İstanbul'un tarihi dokusuna zarar veren kişi ve kurumlara karşı eylemler düzenler, toplantılar tertip eder.

Romanın bir diğer kahramanı olan ve romanın başlarında şüpheli konumunda bulunan Ömer, radikal dinci bir gençtir. Maktullerden Mukadder Kınacı'nın kızı Efsun ile nişanlıdır. Tıp fakültesinde okuyan Ömer, bir dönem cihad etmek için Afganistan'a gittiği ve orada bir Amerikalı binbaşının boğazının kesilmesi olayına şahit olduğu için (s.248) romanın başında şüpheliler arasındadır. Hatta tatillerde kasap olan ailesine yardım etmesi de boğazları kesilerek öldürülen kurbanlar ile Ömer'in kasaplığı arasında bir bağ olduğu izlenimi uyandırır (s.226). Ancak daha sonraki bölümlerden Ömer'in de cinayetle bir bağlantısı olmadığı anlaşılır.

Romanda yer alan bir başka kişi de Ömer'in nişanlısı ve maktul Mukadder Kınacı'nın kızı Efsun'dur. Efsun, ilahiyat fakültesinde okur. O da Ömer gibi muhafazakârlığıyla dikkat çeker. Efsun'un romandaki varlığı kısa sürelidir. Başkomiser Nevzat ile arkadaşları onun ve Ömer'in suçsuzluğuna kanaat getirdikten sonra her ikisinden de bir daha roman boyunca söz edilmez.

Romanda dikkat çeken karakterlerden biri de Âdem Yezdan'dır. "Hakkarili köklü bir aşiretin büyük oğlu” (s.286) olan Âdem Yezdan, çok zengin bir iş adamıdır. Küçük yaşlarda İstanbul'a yerleşmiştir. Dersaadet Turizm adında bir şirketi vardır. Âdem Yezdan, İstanbul'un en değerli arsalarına kendi şirketine ait tesisler yaptırmıştır. Yasal olmayan yollarla bu değerli arsalara sahip olmayı başaran Âdem Yezdan, İstanbul'un tarihi dokusuna zarar veren şahısların başında gelmektedir. Jako papağanlarına meraklı olan Âdem Yezdan'ı bu merakıyla kandıran Demir ve Yekta, onun cezasını en sona bırakarak İstanbul'a en çok zarar veren şahsı en son öldürürler.

Romanın diğer önemli kahramanları Demir ve Yekta'dır. Her ikisi de Başkomiser Nevzat'ın çocukluk arkadaşıdırlar. Yekta kendisini ve Demir'i şöyle tanıtır:

“(...) Ben işsiz güçsüz bir mirasyediyim, Demir ise kendini hayvanlara adamış bir veteriner. Renkli hiçbir şey yok hayatımızda." (s.87)

Demir ve Yekta roman boyunca sakin ve uyumlu yönleriyle öne çıkarlar. Bu sebeple, okuyucuda cinayetleri onların işlemiş olduğuna dair bir şüphe oluşmaz. Çocuklukları birlikte geçen bu üç isim birbirlerine yalnızca iyi anılarıyla değil, birtakım acılarla da bağlıdırlar. Handan ve oğlu Umut'un ölümü yalnızca Yekta'yı değil, Demir'i de derinden sarsmıştır. Bu yüzden de iki arkadaş yolları bir dönem ayrılsa da tekrar bir araya gelip kader birliği ederler. Romanın sonunda da her ikisi aynı gün dünyaya veda ederler. Nevzat; Demir ve Yekta'nın işledikleri suçlara rağmen kötü olduklarını düşünmez. Romanın başkahramanının bu düşüncesi, yazarın düşüncesidir. Ahmet Ümit, kendisiyle yapılan bir röportajda suç işlemenin arka planının da irdelenmesi gerektiğini şu ifadelerle açıklar:

"Benim için suç, vicdanımızla yasa arasında bir yerde duruyor. Bir insan suç işliyorsa, bunun altındaki nedenlere bakmak gerekiyor. Ben suça bakarken, hukukçu, psikolog ya da din adamı gibi bakamam. Yazar, suça bir tanrı gibi bakmalıdır" (Ümit 2006). 
Yazara göre her katil kötü değildir. Onu bu suça iten birtakım sâikler vardır ve bunlara bakılması gerekir. Bu yüzden bir röportajında "Her katil kötü müdür?” sorusuna şu cevabı verir: 2013).

"Asla değildir. Öyle bir an var ki o anda kötülük onu ele geçirmiş olabilir”" (Sağtürk

Romanın kalabalık olmayan şahıs kadrosu içinde romanda çok fazla bir fonksiyonu bulunmayan eski bir polis memuru ve Âdem Yezdan'in koruması olan Ercan (s.469) ve Emniyet Müdürü Mümtaz'a da yer verilir. (s.425)

\section{Zaman}

"Eski Roma'da arabalar hipodromu yedi kez döndükten sonra aynı yere gelirmiş ya..."

Romanın zamanı yaklaşık yedi gündür. Yedi rakamının roman için önemi ve kurgudaki rolü hatırlandığında bu sürenin kurguyu tamamlayan bir unsur olarak yer aldığını söylemek mümkündür. Romanın başında ilk cesede dedektifler “sabahın ilk saatleri” (s.7)'nde ulaşırlar. Sarayburnu'nda Atatürk heykelinin yanına bırakılan cesedin, romanın ilerleyen bölümlerinde cinayet masası ekibinin yaptığı çalışma ile öldürülme zamanı da açıklığa kavuşturulmuş olur. Buna göre ilk cinayet, pazartesi günü işlenmiştir:

“(...) Ölüm lekelerinin oluşması için en az 15 saat gerekir. Bu durumda her ikisi de bulduğumuzdan en az 15 saat önce öldürülmüs olmalı. Necdet Denizel, Sall günü, sabahın 5 'inde bulunmuştu. 15 saat geriye gidersek, pazartesi günü öğleden sonra saat 14'ten önce öldürüldüğ̈̈nü söyleyebiliriz." (s.159)

Diğer maktul Mukadder Kınacı da bir gün sonra öldürülmüştür:

"Mukadder Kınacı'yı ise Çarşamba günü gece l'de bulmuştuk. 15 saat geriye gidersek onun da Salı günü, saat 10'dan önce öldürüldüğünü söyleyebiliriz. Tabii, yaklaşık olarak." (s.159)

Üçüncü cesede "bir gece yarısı" (s.211) ulaşı1ır. Bu cinayet de ikinci cinayetin hemen ardından yirmi dört saat geçmeden işlenmiştir. Cinayetin işlendiği gün, çarşambadır. Perşembe gecesi de dördüncü cesede ulaşılır. (s.328). Beşinci kurbanın başı ve gövdesi birbirinden ayrılır. Cesedin başı öğle saatlerinde Nevzat, Leyla Barkın ile Topkapı Sarayı Müzesi'nde görüşürken gelir. (s.393). Günlerden cumadır. Cuma'yı cumartesiye bağlayan gece ise altıncı cinayet işlenir. (s.509). Son cinayetin günü ise pazardır. (s.544). Cinayetler açığa kavuşup katiller bulununca Yekta, cinayetin zaman kurgusunu nasıl ayarladıklarını Nevzat'a açıklar. Cinayetlerin toplam yedi günde işlendikleri kesinleşir:

$$
\text { “(...) Çaldığımız beyaz minübüs, bütün olayı yedi gün içinde sonlandırmak...” }
$$

"Bir dakika, bir dakika," diye kestim sözünü. Bizim hesabımıza göre olaylar altı günde gerçekleşmişti. Illk cesedi Salı akşamının ilk saatlerinde bırakmadınız mı?"

"Pazartesi'nin geç saatlerinde, on ikiye doğru. Bütün olaylarl yedi rakamıyla bağlamak istiyorduk. Tabii bu, benim fikrimdi. Planımızın aksaksız işlemesi için aylarca kurbanları izledik... Saat kaçta evden çıklyorlar, kaçta işe gidiyorlar... Birini öldürdükten sonra ötekini kaçırıyorduk." (s.555)

Romanın zaman aralığının kısa tutulması ve cinayetlerin arka arkaya işlenmesi romandaki gerilimi sürekli diri tutar. Romanın başından sonuna kadar bu gerilim devam eder.

\section{Mekân}

"Seni öldürmemi isteyen bizzat bu şehir"

İstanbul Hatırası romanında mekân kurgusu bir hayli karmaşık ve dağınıktır. Mekânlar olay örgüsüyle iç içe geçmiş, parçalanmış ve kurgunun seyrine göre dağınık bir hal almıştır. Romanda tarihi mekânlar ön plandadır. İstanbul'un ilk yerleşim yeri olan ve bugün Tarihi 
yarımada olarak adlandırılan kısım romanın mekân bütününü oluşturur. Romanın başkahramanı Başkomiser Nevzat, tarihe meraklı olduğu için tarihi bir semt olan Balat’ta yaşar. (s.16). Yine İstanbul'un en eski semtlerinden olan Samatya'ya sevgi duyar:

“(...) Yaşadığım Balat kadar olmasa da hep sevmişimdir Samatya'yl; İstanbul'u İstanbul yapan kadim semtlerden biridir." (s.16).

Başkomiser Nevzat, roman boyunca yalnız suçluları araştıran bir dedektif değil, İstanbul'u mekân bağlamında da okuyucuya tanıtan bir tarihçi gibidir. Yazar, kurgu içerisinde Nevzat'a yardımcı olarak da İstanbul şehir tarihini çok iyi bilen Topkapı Müzesi müdiresi Leyla Barkın'ı tayin etmiştir. Nevzat'ın İstanbul şehir tarihine dair ayrıntılarda tıkandığı yerlerde devreye Leyla Barkın girer.

Romanda, mekânları șekillendiren, cinayetlerdir. Yedi cesedin, İstanbul'un farklı tarihi mekânlarına bırakıldığg yukarıda da belirtilmişti. Bu mekânlardaki tarihi yapılar, cesetlerin bırakılmasında önemli birer belirleyendir. Cesetler dönemin hükümdarı ve hükümdarın yaptırdığ 1 önemli bir yapıyı işaret eder. Bu durumda düzenleme şu şekildedir:

1. Kral Byzas: Sarayburnu

2. Constatinus: Çemberlitaş sütunu

3. II. Teodosius: Altınkap1

4. I. Justinianus: Ayasofya

5. Fatih Sultan Mehmed: Fatih Camii

6. Kanuni Sultan Süleyman: Süleymaniye Camii (Hükümdar olmasa da mimari anlamda dönemin en önemli ismi olan Mimar Sinan da bu bölümde anılır ve ceset de Süleymaniye Camii'nin yanında bulunan Mimar Sinan Türbesi'nde bulunur.)

7. Atatürk: Sarayburnu'ndaki Atatürk Heykeli (Sarayburnu, ilk cesedin bırakıldığı yerdir. Katiller, yedinci cesedi başladıkları yere bırakmayı uygun bulmuşlardır. Ancak yedinci cesette işaret edilen dönem, farklılaşır. İlk ceset, Kral Byzas dönemini işaret ederken, yedinci ceset kronolojik akışa uygun olarak, İstanbul'un Cumhuriyet dönemindeki zamanını işaret eder.).

Yazar, bu yedi ana mekânı kullanarak, İstanbul'un Kral Byzas döneminden Cumhuriyet dönemine kadar olan sürecinde kolektif belleğe ait birçok mekânı romana dâhil eder. Bunu yaparken de yedi bölüme ayırdığı romanın her bir bölümünün başında bir tarihi kurgu kullanır. Bunlar her bölüm başında yaklaşık iki veya üç sayfadan oluşur. Üstkurmaca olarak değerlendirilebilecek bu bölümlerden birincisinde Kral Byzas'ın Tanrı'ya bir boğa kesip kurban ettiği bir sahne tasvir edilir. Daha sonra da bu bölümde tarihi yarımadada nasıl bir tahribat yapıldığ 1 vurgusu sürekli dile getirilir. Romanın bu bölümü boyunca Bizans'ın efsanevi tarihine ve buradaki ilk yerleşime dair bilgiler verilir (s.47)

Şehir tarihine dair bilgilerin yanısıra, Küçük Ayasofya, Hipodrom, Sultanahmet Meydanı, Ayasofya gibi pek çok tarihi mekân bu bölümde anılır. Bunun yanında herkesin çok bilmediği Molla Zeyrek Camii (s.57) gibi mekânlar da zikredilir.

İkinci bölümde imparator Constantinus'un Çemberlitaş sütununu inşa ettikten sonra kırk gün kırk gece süren bir şenlik düzenlediği ve Tanrı'ya şükran duygularını ilettiği bir sahne tasvir edilir. Burada da yine yer yer varlığını koruyan ama tehlike altında olan ve herkesin bilmediği mekânlara da yer verilir. Bunlardan Atik Ali Paşa Camii (s.104)., 2. Mahmud Türbesi (s.114), Dikilitaş (s.162), Türk İslam Eserleri Müzesi’nde bulunan İbrahim Paşa Sarayı (s.168) gibi mekânlar dikkat çekerler.

Üçüncü bölümde imparator II. Teodosios'un atının üstünde vakur bir eda ile, inşa ettirdiği Altınkapı'dan şehre girişi tasvir edilir. Burada da yine şehir tarihi için önemli olan Ivaz Efendi Camii (s.229), Yedikule Zindanları (s.280), Fatih’teki Kız Taşı (Markianos Sütunu) (s.309) gibi mekânlara yer verilir.

Dördüncü bölümde Roma imparatoru Justinianos'un beş yılda yapımı tamamlanan Ayasofya önünde sevgilisi Teodora ile mabede gururla bakışı tasvir edilir. Bu bölümde de Cafer 
Ağa Medresesi (s.324), Soğuk Çeşme Sokağı (s.329), Aya İrini Kilisesi (s.329), Köprülü Mehmed Paşa Camii (s.351)'ne yer verilir.

Beşinci bölümde Fatih'in İstanbul'u fethettikten sonra Ayasofya'da ellerini semaya açıp, bu başarısından dolayı Allah'a şükrettiği bölüm tasvir edilir. (s.405-406-407). Beşinci bölümde mekân ağırlıklı olarak Fatih Camii ve Mimar Sinan'ı türbesidir.

Altıncı bölümde, Kanuni Sultan Süleyman'ın Mimar Sinan ile birlikte, inşası tamamlanan Süleymaniye Camii'nin açılışındaki şükür ve sevinçleri tasvir edilir (s.497-498-499). Bu arada Mihrimah Sultan Camii'nin inşasında Mimar Sinan'a ilham olan Kanuni'nin kızı Mihrimah Sultan'a duyduğu gizli aşka dair menkıbeye yer verilir. (s.504). Süleymaniye Camii de burada sikça geçer.

Yedinci bölümde Nevzat, Yekta ve Demir'in denizden İstanbul'a bakarken hayal kırıklığı içinde bir film şeridi gibi gördükleri çocukluklarının İstanbul'unun nasıl bir tahribata maruz kaldığı tasvir edilir. (s.559-560) Bu kısım romanın çözülüşünün de gerçekleştiği kısımdır.

\section{Bakış Açısı}

"Toplum çürümüs, neresinden tutsak, elimizde kallyor"

Yazar, romanın başından itibaren İstanbul'un yaşadığı tahribata vurgu yapar. Kolektif belleğe ait tarihi dokunun şahsi çıkarlar uğruna nasıl yok edildiğine dikkat çeker. Yöneticilerin bu konuda hiçbir şey yapmamasını, tahribata göz yummasını eleştirir. (s.58).

Tarihi yapıların hoyratça hırpalanması Nevzat'ın İSD binasının girişinde gördüğü bir İstanbul fotoğrafi üzerinden verilir:

"Büyük Bizans Sarayı'nın üzerine yapılan beş yıldızlı otelin oluşturduğu tahribatı, Süleymaniye Camii'nin duvarların süsleyen eşsiz hat yazılarının bozulmaya yüz tutmuş halini, Bizans döneminden kalma Bukaleon Sarayl'nın çöplüğe dönmüş görünümünü, Kadırga'da ylkılmaya yüz tutmuş eski, ahşap İstanbul evlerini, Beyazıt'ta Roma sütunlarının üzerinde kadın iç çamaşıırı sergileyen seyyar satıcıyı, Marmaray kazısında alelacele kazılan antik limanın içler acısı durumunu, nakışlı mermerine siyah yağlı boyayla, "En büyük asker bizim asker yazılmış Osmanlı çeşmesinin trajikomik halini, Topkapı Sarayı'nda paslanan antika silahları, çürüyen resimleri, giysileri " (s.55) gösteren bu fotoğraf şehrin içine düştüğü trajik durumun özeti gibidir.

Romanda, yapımı 2014 yılında tamamlanmış olan Haliç Metro Köprüsü'nün şehrin siluetine zarar verdiğine yönelik eleştirel yaklaşım da yine Namık Karaman üzerinden aktarılır:

"Hem şu Haliç'teki eylem neymiş bakalım?"

"Büyük suç," dedi Namık alaycı bir gülümsemeyle. "Metro yolu için Haliç'in üzerine yapılacak köprüye karşı çıktık. Çünkü şehrin siluetini bozacaktı. Süleymaniye Camii'nin muhteşem görüntüsünü kirletecekti.” (s.59)

Yine Namık Karaman aracıllğıyla yöneticilere eleştirel yaklaşım sürdürülür. İstanbul'un tarihi dokusunun korunmasına dair çalışmaların yetersizliği vurgulanır:

"Sultanahmet bölgesinin Müze Adası'na çevrilmesi... Kültür Bakanlı̆̆ı'nın nihayet aklı başına geldi. Yıllardır önerdiğimiz projeyi sonunda gündeme aldılar." (s.61)

Yukarıdaki alıntılar yazarın, roman içerisine serpiştirdiği eleştirel yaklaşımlar. Romanın başından sonuna kadar, maktullerin ortadan kaldırılan bedenleri ile birlikte İstanbul'un da para kazanma hırsı ile hareket eden insanların elinde nasıl yavaş yavaş öldürüldüğ̈̈ne vurgu yapılır.

\section{Sonuç}

İstanbul Hatırası romanı, olay örgüsüyle karmaşık bir roman olarak dikkat çeker. Romanın iki cephesi vardır: Birincisi klasik bir polisiye romanda görülen dedektifin katili arama çabaları, ikincisi İstanbul'un Bizans, Roma ve Osmanlı dönemindeki mimarisine maktullerin 
cesetlerinin bırakıldığı mekânlar üzerinden yapılan göndermelerdir. Her ikisi birleştiğinde romanda iç içe geçmiş bir olay örgüsü oluşur.

Roman, yedi günlük bir zaman diliminde geçer. Yedi güne sığdırılan yedi cinayet üzerinden ilerleyen romanda tarihi olaylar da işin içine girdiğinde parçalanmış bir zamandan söz etmek mümkündür. Maktullerin avucuna bırakılan sikkeler aracılığılla geri dönüşlerle, İstanbul'un farklı dönemlerine gidilerek, o dönemde inşa edilmiş yapıların geçmişleri irdelendikten sonra tekrar gerçek zamana dönülür.

Romandaki mekânlar, polisiye romanın gizem ve gerilimine bağlı olarak kapalı mekânlardır. Şüpheli bulunan şahıslarla görüşülen mekânlar bu bağlamda değerlendirilebilir. Bunun yanında tarihi mekânlarda kurgu içerisinde geriye dönüşlerle ve ana kurgudan farklı bir biçimde sikkeler aracılığıyla romana dâhil edilir. Tarihi mekânlarla esas olay arasındaki bağlantı da romanın her bir bölümünde Sarayburnu'na ilk yerleşim, Çemberlitaş Sütunu, Altınkapı, Ayasofya, Fatih Camii, Süleymaniye Camii gibi yapıların inşası esnasındaki bir sahnenin tasviriyle kurulur.

Romanın şahıs kadrosu çok geniş değildir. Klasik polisiye roman kurgularında olduğu gibi cinayetlerin izini süren bir polis ve yardımcıları vardır. Roman boyunca şüpheli olarak görülen ve birtakım ipuçlarının kendilerini işaret ettiği kahramanlar sorgulanır. Sonuç olarak hiç beklenmedik iki şahsın katil olduğu anlaşılır. Cinayetin beklenmedik bir biçimde sonuçlanması Ahmet Ümit'in polisiye romanlarının alışılmış özelliklerinden biridir.

Romanın en dikkat çeken yönü, yazarın İstanbul'un tarihi dokusunun bozuluşundan duyduğu endişeyi ön plana çıkarmasıdır. Bu bağlamda yazar, yöneticilerin duyarsızlığına ve şehri bekleyen tehlikeye her firsatta vurgu yapar. Bu yönüyle bakıldığında İstanbul Hatırası romanının bir şehrin tarihi dokusunun yok edilişine duyulan tepkinin ürünü bir eser olduğunu ve bu tepkinin de en az romanın polisiye kurgusu kadar öne çıktığını söylemek mümkündür. Yazar, yalnızca polisiye bir eser yazmak amacında değildir. Çeşitli imparatorluklara ev sahipliği yapmış, birçok medeniyetten izler taşıyan kadim bir şehrin insan eliyle hoyratça tahrip edilmesine dikkat çeker. Romanda işlenen cinayetlerin maktullerinin ortak noktası İstanbul'a zarar veren veya zarar verilmesine kapı aralayan kişiler olmalarıdır. Yazar maddi menfaat sağlamak için nüfuzunu kullanan bürokrat, daha fazla para kazanmak için kanunları hiçe sayan müteahhit ve diğer meslek mensuplarından seçtiği maktullere hazırladığı sonla âdeta İstanbul'un intikamını onlardan almaktadir.

\section{Kaynakça}

Aytaç, G. (2012). Çağdaş Türk Romanı Üzerine İncelemeler, Ankara: Doğu Batı Yayınları.

Çelik Yalçın, D. (2005). Yeni Tarihselcilik Kuramı ve Türk Edebiyatında Postmodern Tarih Romanları, Ankara: Akçağ Yayınları.

Ecevit, Y. (2006). Türk Romanında Postmodernist Açılımlar, İstanbul: İletişim Yayınları.

Gezer, H. (2006). Türk Edebiyatında Polisiye Roman ve Ahmet Ümit'in Polisiye Roman Kurguları, Süleyman Demirel Üniversitesi Sosyal Bilimler Enstitüsü, Yayımlanmamış Yüksek Lisans Tezi, Isparta.

Gülgûn, S. (26 Eylül 2002). Polisiye, Edebiyatın Piçi Değil, Kremasıdır, Milliyet Gazetesi.

Oktay, N. (21 Eylül 2003). Okurla Satranç Oynamam, Milliyet Gazetesi.

Özkartal, M. Z. (5 Haziran 2010). Yedi Günde Yedi Cinayet, Milliyet Gazetesi.

Sağtürk, T. (9 Haziran 2013). Her İnsan Potansiyel Bir Katildir, Radikal Gazetesi. 
Sayın, Ö. (Aral1k2010-Ocak 2011). Edebiyatın Asıl Amacı İnsan Ruhunu Anlamaktır, Notos Öykü Dergisi, 25.

Ümit, A. (2010). İstanbul Hatırası, İstanbul: Everest Yayınları.

Ümit, A. (17 Mart 2006). Yazar Suça Tanrı Gibi Bakmalıdır, Radikal Gazetesi. 